Cellular Physiology
and Biochemistry and Biochemistry Published online: March 04,2016

Accepted: February 12, 2016

\title{
Stimulation of Eryptosis by Combretastatin A4 Phosphate Disodium (CA4P)
}

\author{
Elena Signoretto ${ }^{a, b, c}$ Rosi Bissinger ${ }^{a, b}$ Michela Castagna ${ }^{c}$ Florian Lang ${ }^{a, b}$
}

Departments of aCardiology \& Vascular Medicine, and 'Physiology, University of Tuebingen, Tuebingen, Germany; 'Department of Pharmacological and Biomolecular Sciences, Università degli Studi di Milano, Milano, Italy

\section{Key Words}

Phosphatidylserine $\bullet$ Cell volume $\bullet$ Eryptosis $\bullet$ Cell membrane scrambling $\bullet$ Calcium

\begin{abstract}
Background/Aims: Combretastatin A4 phosphate disodium (CA4P) is utilized for the treatment of malignancy. The substance has previously been shown to trigger suicidal cell death or apoptosis. Similar to apoptosis of nucleated cells, erythrocytes may enter suicidal death or eryptosis, characterized by cell shrinkage and cell membrane scrambling with phosphatidylserine translocation to the erythrocyte surface. Stimulators of eryptosis include increase of cytosolic $\mathrm{Ca}^{2+}$ activity $\left(\left[\mathrm{Ca}^{2+}\right]_{j}\right)$, ceramide, oxidative stress and ATP depletion. The present study explored, whether CA4P induces eryptosis and, if so, to gain insight into mechanisms involved. Methods: Flow cytometry has been employed to estimate phosphatidylserine exposure at the cell surface from annexin-V-binding, cell volume from forward scatter, $\left[\mathrm{Ca}^{2+}\right]_{i}$ from Fluo3-fluorescence, reactive oxygen species (ROS) abundance from DCF fluorescence, glutathione (GSH) abundance from CMF fluorescence and ceramide abundance from fluorescent antibodies. In addition cytosolic ATP levels were quantified utilizing a luciferin-luciferase-based assay and hemolysis was estimated from hemoglobin concentration in the supernatant. Results: A 48 hours exposure of human erythrocytes to CA4P $(\geq 50 \mu \mathrm{M})$ significantly increased the percentage of annexin-V-binding cells and significantly decreased forward scatter. CA4P did not appreciably increase hemolysis. Hundred $\mu$ M CA4P significantly increased Fluo3-fluorescence. The effect of CA4P $(100 \mu \mathrm{M})$ on annexin-V-binding was significantly blunted, but not abolished, by removal of extracellular $\mathrm{Ca}^{2+}$. CA4P $(\geq 50 \mu \mathrm{M})$ significantly decreased GSH abundance and ATP levels but did not significantly increase ROS or ceramide. Conclusions: CA4P triggers cell shrinkage and phospholipid scrambling of the erythrocyte cell membrane, an effect at least in part due to entry of extracellular $\mathrm{Ca}^{2+}$ and energy depletion.

\section{Introduction}

Combretastatin A4 phosphate disodium (CA4P) is an antiangiogenic drug [1-35] effective against several malignancies $[1,2,10,12,15,16,18,30,36-61]$. The substance has 


\section{Cellular Physiology Cell Physiol Biochem 2016;38:969-981

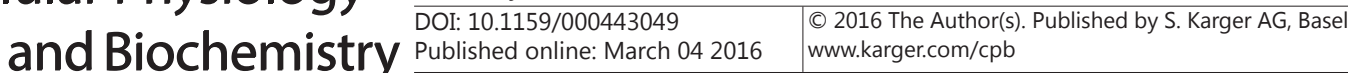

Signoretto et al.: CA4P-Induced Eryptosis

been shown to depolymerize microtubules [22], induce autophagy [4, 62], counteract tumor cell migration [63], and trigger apoptosis [64].

Similar to apoptosis of nucleated cells, erythrocytes may enter eryptosis [65], the suicidal death of erythrocytes characterized by cell shrinkage [66] and cell membrane scrambling with phosphatidylserine translocation to the cell surface [65]. Eryptosis may be triggered by increase of cytosolic $\mathrm{Ca}^{2+}$ activity $\left(\left[\mathrm{Ca}^{2+}\right]_{\mathrm{i}}\right)[65]$. Eryptosis may further involve ceramide formation [67], oxidative stress [65], energy depletion [65], caspases [65, 68, 69], and a variety of kinases including casein kinase $1 \alpha$, Janus-activated kinase isoform JAK3, protein kinase C, and p38 kinase [65]. Eryptosis is inhibited by AMP activated kinase, cGMPdependent protein kinase, PAK2 kinase and sorafenib/sunitinib sensitive kinases [65]. Eryptosis may be triggered by a wide variety of small molecules [65, 70-100].

The present study explored, whether CA4P is capable to stimulate eryptosis. To this end, human erythrocytes from healthy volunteers were treated with CA4P and phosphatidylserine surface abundance, cell volume, and $\left[\mathrm{Ca}^{2+}\right]_{\mathrm{i}}$ determined by flow cytometry.

\section{Materials and Methods}

Erythrocytes, solutions and chemicals

Fresh Li-Heparin-anticoagulated blood samples were kindly provided by the blood bank of the University of Tübingen. The study is approved by the ethics committee of the University of Tübingen (184/2003 V). The blood was centrifuged at $120 \mathrm{~g}$ for $20 \mathrm{~min}$ at $21^{\circ} \mathrm{C}$ and the platelets and leukocytes-containing supernatant was disposed. Erythrocytes were incubated in vitro at a hematocrit of $0.4 \%$ in Ringer solution containing (in $\mathrm{mM}$ ) $125 \mathrm{NaCl}, 5 \mathrm{KCl}, 1 \mathrm{MgSO}_{4}, 32 \mathrm{~N}$-2-hydroxyethylpiperazine-N-2-ethanesulfonic acid (HEPES; pH 7.4), 5 glucose, $1 \mathrm{CaCl}_{2}$, at $37^{\circ} \mathrm{C}$ for 48 hours. Where indicated, $\mathrm{CaCl}_{2}$ was replaced by EDTA and/or erythrocytes were exposed for 48 hours to Combretastatin A4 phosphate disodium (CA4P) (Sigma Aldrich, Hamburg, Germany).

\section{Annexin-V-binding and forward scatter}

After incubation under the respective experimental condition, a $100 \mu \mathrm{l}$ cell suspension was washed in Ringer solution containing $5 \mathrm{mM} \mathrm{CaCl}_{2}$ and then stained with Annexin-V-FITC (1:200 dilution; ImmunoTools, Friesoythe, Germany) in this solution at $37^{\circ} \mathrm{C}$ for $20 \mathrm{~min}$ under protection from light. The annexin-Vabundance at the erythrocyte surface was subsequently determined on a FACS Calibur (BD, Heidelberg, Germany). Annexin-V-binding was measured with an excitation wavelength of $488 \mathrm{~nm}$ and an emission wavelength of $530 \mathrm{~nm}$. A marker (M1) was placed to set an arbitrary threshold between annexin-V-binding cells and control cells. The same threshold was used for untreated and CA4P treated erythrocytes. A dot plot of forward scatter (FSC) vs. side scatter (SSC) was set to linear scale for both parameters. The threshold of forward scatter was set at the default value of " 52 ".

Intracellular $\mathrm{Ca}^{2+}$

After incubation, erythrocytes were washed in Ringer solution and loaded with Fluo-3/AM (Biotium, Hayward, USA) in Ringer solution containing $1 \mathrm{mM} \mathrm{CaCl}_{2}$ and $5 \mu \mathrm{M}$ Fluo-3/AM. The cells were incubated at $37^{\circ} \mathrm{C}$ for $30 \mathrm{~min} . \mathrm{Ca}^{2+}$-dependent fluorescence intensity was measured with an excitation wavelength of 488 $\mathrm{nm}$ and an emission wavelength of $530 \mathrm{~nm}$ on a FACS Calibur.

Hemolysis

After incubation at $37^{\circ} \mathrm{C}$, the samples were centrifuged ( $10 \mathrm{~min}$ at $2000 \mathrm{rpm}, \mathrm{RT}$ ), and the supernatants were harvested. As a measure of hemolysis, the hemoglobin $(\mathrm{Hb})$ concentration of the supernatants was determined photometrically at $405 \mathrm{~nm}$. The absorption of the supernatant of erythrocytes lysed in distilled water was defined as $100 \%$ hemolysis.

\section{Reduced glutathione}

The content of reduced glutathione was determined using 5-chloromethylfluorescein diacetate (CMFDA) staining. After treatment, cells were spun down, incubated in Ringer solution containing 1 $\mu \mathrm{M}$ of CMFDA (Santa Cruz Biotechnology, USA) for $45 \mathrm{~min}$, washed once, and resuspended in $200 \mu \mathrm{l}$ of 
Ringer solution. The fluorescence intensity was measured with flow cytometry (FACS-calibur from Becton Dickinson; Heidelberg, Germany) at an excitation wavelength of $488 \mathrm{~nm}$ and an emission wavelength of $530 \mathrm{~nm}$.

Reactive oxidant species (ROS)

Oxidative stress was determined utilizing 2',7'-dichlorodihydrofluorescein (DCF) diacetate. After incubation, a $100 \mu \mathrm{l}$ suspension of erythrocytes was washed in Ringer solution and then stained with DCF (Sigma, Schnelldorf, Germany) in Ringer containing DCF diacetate at a final concentration of $10 \mu \mathrm{M}$. Erythrocytes were incubated at $37^{\circ} \mathrm{C}$ for $30 \mathrm{~min}$ in the dark and then washed in PBS. The DCF-loaded erythrocytes were resuspended in $200 \mu$ Ringer solution, and ROS-dependent fluorescence intensity was measured at an excitation wavelength of $488 \mathrm{~nm}$ and an emission wavelength of $530 \mathrm{~nm}$ on a FACS Calibur (BD).

\section{Ceramide abundance}

For the determination of ceramide, a monoclonal antibody-based assay was used. After incubation, cells were stained for 1 hour at $37^{\circ} \mathrm{C}$ with $1 \mu \mathrm{g} / \mathrm{ml}$ anti ceramide antibody (clone MID 15B4, Alexis, Grünberg, Germany) in PBS containing 0.1\% bovine serum albumin (BSA) at a dilution of 1:10. The samples were washed twice with PBS-BSA. Subsequently, the cells were stained for 30 minutes with polyclonal fluorescein isothiocyanate (FITC) conjugated goat anti-mouse IgG and IgM specific antibody (Pharmingen, Hamburg, Germany) diluted 1:50 in PBS-BSA. Unbound secondary antibody was removed by repeated washing with PBS-BSA. The samples were then analyzed by flow cytometric analysis with an excitation wavelength of 488 $\mathrm{nm}$ and an emission wavelength of $530 \mathrm{~nm}$.

\section{Intracellular ATP concentration}

For the determination of intracellular ATP, $80 \mu \mathrm{l}$ of erythrocyte pellets were incubated for $24 \mathrm{~h}$ at $37^{\circ} \mathrm{C}$ in Ringer solution (final hematocrit 4.7\%). All subsequent manipulations were performed at $4^{\circ} \mathrm{C}$ to avoid ATP degradation. Cells were lysed in distilled water, and proteins were precipitated by addition of $\mathrm{HClO}_{4}(6 \%)$. After centrifugation, an aliquot of the supernatant $(400 \mu \mathrm{l})$ was adjusted to $\mathrm{pH} 7.7$ by addition of saturated $\mathrm{KHCO}_{3}$ solution. After dilution of the supernatant, the ATP concentrations of the aliquots were determined utilizing the luciferin-luciferase assay kit (Roche Diagnostics) on a luminometer (BertholdBiolumat LB9500, Bad Wildbad, Germany) according to the manufacturer's protocol.

\section{Statistics}

Data are expressed as arithmetic means \pm SEM. As indicated in the figure legends, statistical analysis was made using ANOVA with Tukey's test as post-test and $t$ test as appropriate. $\mathrm{n}$ denotes the number of different erythrocyte specimens studied. Since different erythrocyte specimens used in distinct experiments are differently susceptible to triggers of eryptosis, the same erythrocyte specimens have been used for control and experimental conditions.

\section{Results}

The present study explored whether Combretastatin A4 phosphate disodium (CA4P) stimulates eryptosis, the suicidal erythrocyte death characterized by cell shrinkage and phospholipid scrambling of the cell membrane with phosphatidylserine translocation to the cell surface.

Forward scatter was determined by flow cytometry as a measure of erythrocyte volume. Prior to measurements, the erythrocytes were incubated for 48 hours in Ringer solution without or with CA4P (10 - $100 \mu \mathrm{M})$. As illustrated in Fig. 1, CA4P decreased erythrocyte forward scatter, an effect reaching statistical significance at 50 and $100 \mu \mathrm{M}$ CA4P (15\%, $25 \%$ decrease respectively). Moreover, exposure of erythrocytes to CA4P was followed by a significant increase of the percentage of shrunken erythrocytes (Fig. 1C), an effect reaching statistical significance at $25 \mu \mathrm{M}$ CA4P (233\% increase). CA4P treatment simultaneously increased the percentage of swollen erythrocytes (Fig. 1D), an effect reaching statistical significance at $50 \mu \mathrm{M}$ CA4P (75\% increase). 


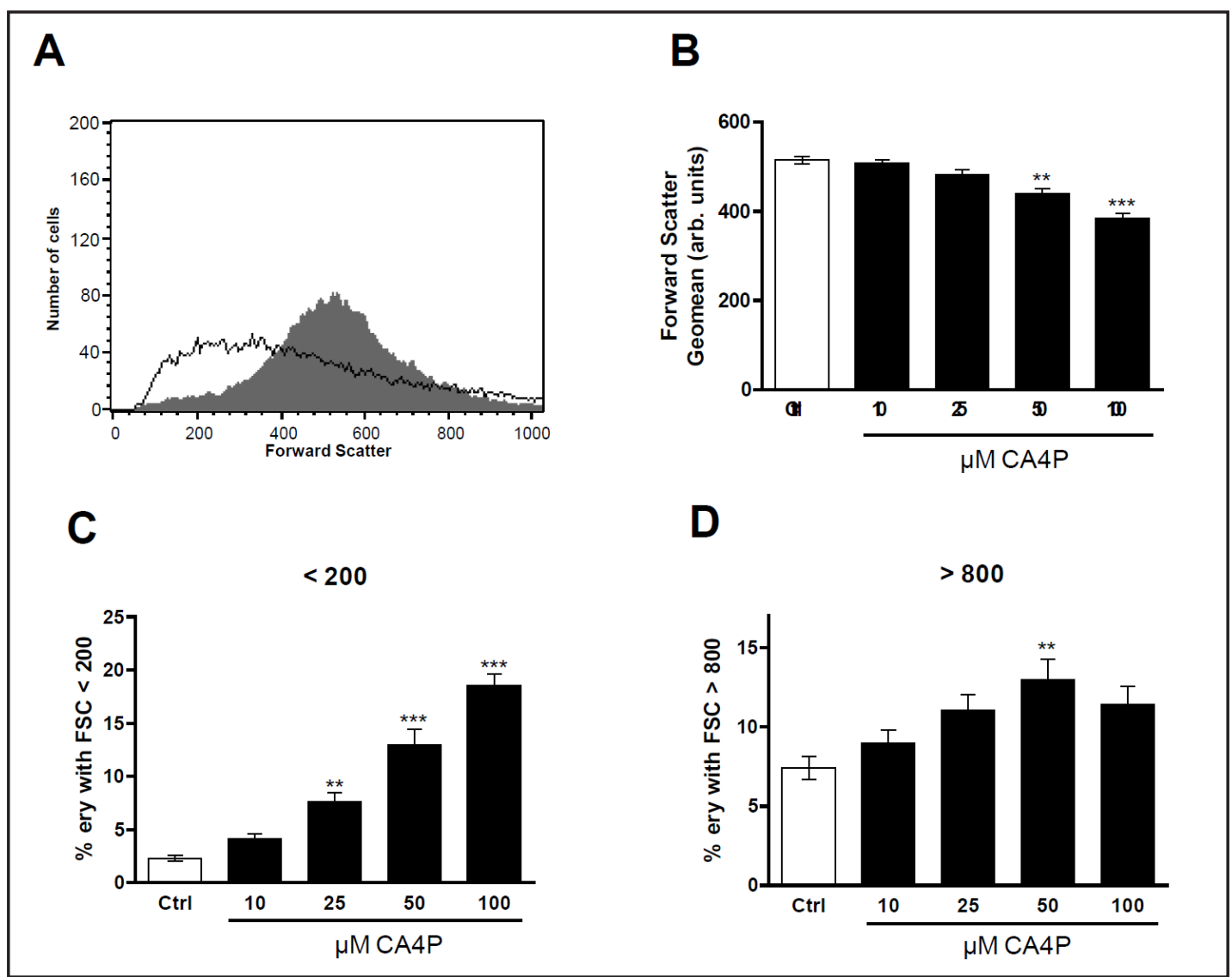

Fig. 1. Effect of CA4P on erythrocyte forward scatter. A. Original histogram of forward scatter of erythrocytes following exposure for 48 hours to Ringer solution without (grey area) and with (black line) presence of $100 \mu \mathrm{M}$ CA4P. B. Arithmetic means \pm SEM ( $=13$ ) of the erythrocyte forward scatter (FSC) following incubation for 48 hours to Ringer solution without (white bar) or with (black bars) CA4P (10 - $100 \mu \mathrm{M})$. C. Arithmetic means \pm SEM $(n=13)$ of the percentage erythrocytes with forward scatter $(F S C)<200$ following incubation for 48 hours to Ringer solution without (white bar) or with (black bars) CA4P (10 - $100 \mu \mathrm{M})$. D. Arithmetic means \pm SEM $(n=13)$ of the percentage erythrocytes with forward scatter $(F S C)>800$ following incubation for 48 hours to Ringer solution without (white bar) or with (black bars) CA4P (10 - $100 \mu \mathrm{M})$. ${ }^{* *}(\mathrm{p}<0.01),{ }^{* * *}(\mathrm{p}<0.001)$ indicates significant difference from the absence of CA4P (ANOVA).

Phosphatidylserine exposing erythrocytes were identified utilizing annexin-V-binding, as determined by flow cytometry. Prior to measurements, the erythrocytes were again incubated for 48 hours in Ringer solution without or with CA4P $(10-100 \mu \mathrm{M})$. As shown in Fig. 2, a 48 hours exposure to CA4P increased the percentage of phosphatidylserine exposing erythrocytes, an effect reaching statistical significance at $50 \mu \mathrm{M}$ CA4P (212\% increase).

In order to test whether CA4P induces hemolysis, the hemoglobin concentration was determined in the supernatant. As a result, the percentage of hemolytic erythrocytes was not significantly different between exposure to Ringer solution $(1.9 \pm 0.2 \%, \mathrm{n}=13)$, and following exposure to $10 \mu \mathrm{M}(1.8 \pm 0.2 \%, \mathrm{n}=13), 25 \mu \mathrm{M}(1.9 \pm 0.3 \%, \mathrm{n}=13), 50 \mu \mathrm{M}(2.5 \pm$ $0.3 \%, \mathrm{n}=13)$, and $100 \mu \mathrm{M}(2.7 \pm 0.3 \%, \mathrm{n}=13) \mathrm{CA} 4 \mathrm{P}$.

Fluo3-fluorescence was employed to estimate cytosolic $\mathrm{Ca}^{2+}$ activity $\left(\left[\mathrm{Ca}^{2+}\right]_{\mathrm{i}}\right)$. Prior to measurements, the erythrocytes were incubated for 48 hours in Ringer solution without or with CA4P $(10-100 \mu \mathrm{M})$. As shown in Fig. 3, a 48 hours exposure to $100 \mu \mathrm{M}$ CA4P significantly increased the Fluo3-fluorescence (54\% increase).

A next series of experiments explored, whether the CA4P-induced cell membrane scrambling required entry of extracellular $\mathrm{Ca}^{2+}$. To this end, erythrocytes were incubated 
A

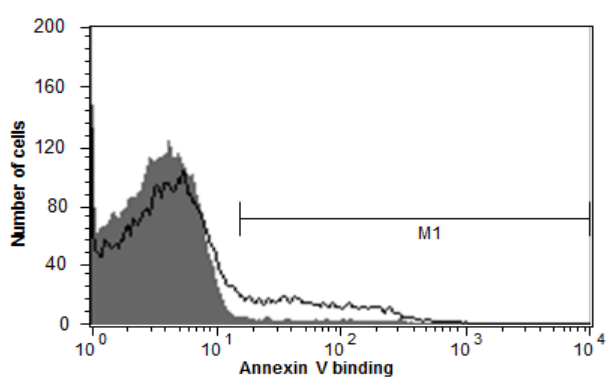

B

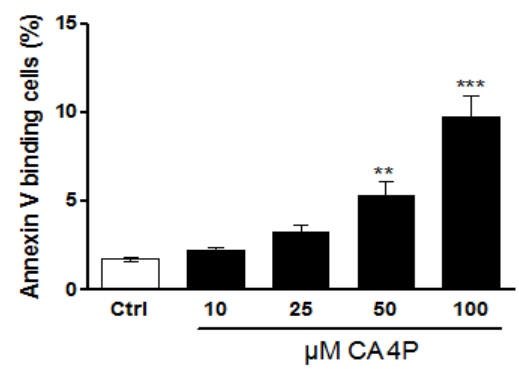

Fig. 2. Effect of CA4P on phosphatidylserine exposure. A. Original histogram of annexin-V-binding of erythrocytes following exposure for 48 hours to Ringer solution without (grey area) and with (black line) presence of $100 \mu \mathrm{M}$ CA4P. B. Arithmetic means \pm SEM ( $n=13)$ of erythrocyte annexin-V-binding following incubation for 48 hours to Ringer solution without (white bar) or with (black bars) CA4P (10 - $100 \mu \mathrm{M}$ ). ${ }^{* *}(\mathrm{p}<0.01),{ }^{* * *}(\mathrm{p}<0.001)$ indicates significant difference from the absence of CA4P (ANOVA).

\section{A}

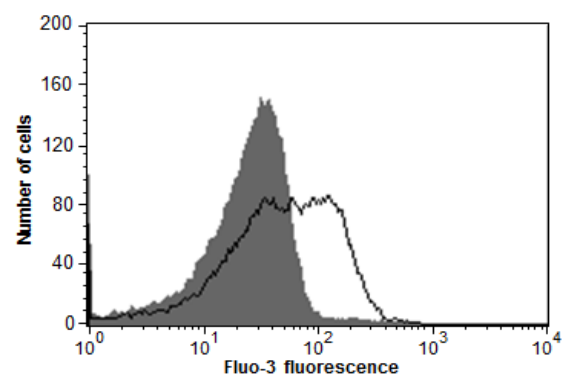

B

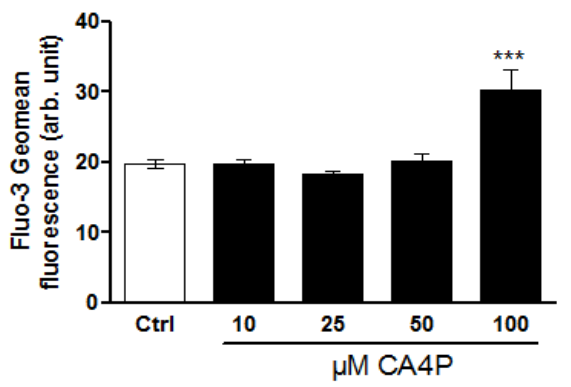

Fig. 3. Effect of CA4P on Fluo3-fluorescence. A. Original histogram of Fluo3-fluorescence reflecting cytosolic $\mathrm{Ca}^{2+}$ activity in erythrocytes following exposure for 48 hours to Ringer solution without (grey area) and with (black line) presence of $100 \mu \mathrm{M}$ CA4P. B. Arithmetic means \pm SEM ( $n=13)$ of erythrocyte Fluo3fluorescence following incubation for 48 hours to Ringer solution without (white bar) or with (black bars) CA4P $(10-100 \mu \mathrm{M}) .{ }^{* * *}(\mathrm{p}<0.001)$ indicates significant difference from the absence of CA4P (ANOVA).

for 48 hours in the absence or presence of 50 or $100 \mu \mathrm{M}$ CA4P in the presence or nominal absence of extracellular $\mathrm{Ca}^{2+}$. As illustrated in Fig. 4, CA4P again profoundly increased the percentage of annexin-V-binding erythrocytes. The effect of $100 \mu \mathrm{M}$ CA4P was significantly blunted following removal of extracellular $\mathrm{Ca}^{2+}$. However, even in the absence of extracellular $\mathrm{Ca}^{2+}, \mathrm{CA} 4 \mathrm{P}$ significantly increased the percentage of annexin-V-binding erythrocytes. Thus, CA4P-induced cell membrane scrambling was in large part but not exclusively due to mechanisms dependent on entry of extracellular $\mathrm{Ca}^{2+}$.

A further series of experiments was performed to elucidate the effect of CA4P on the content of reduced Glutathione (GSH). To this end, erythrocytes were incubated for 48 hours in the absence or presence of 50 and $100 \mu \mathrm{M}$ CA4P. As illustrated in Fig. 5, CA4P (50, $100 \mu \mathrm{M}$ CA4P) significantly decreased the content of GSH (by $47 \%$ and $64 \%$, respectively).

To explore the effect of CA4P on oxidative stress, reactive oxygen species (ROS) was estimated utilizing $2^{\prime}, 7^{\prime}$-dichlorodihydrofluorescein (DCF) diacetate. As a result, the DCF fluorescence was significantly ( $\mathrm{p}<0.001)$ lower following exposure to $50 \mu \mathrm{M}(16.3 \pm 0.9$ a.u., $\mathrm{n}=13)$ or $100 \mu \mathrm{M}(15.6 \pm 0.8$ a.u., $\mathrm{n}=13)$ CA4P concentration than following exposure to Ringer solution ( $23.1 \pm 1.1$ a.u., $n=13)$. Accordingly, a 48 hours exposure to CA4P decreased but did not increase ROS formation. 


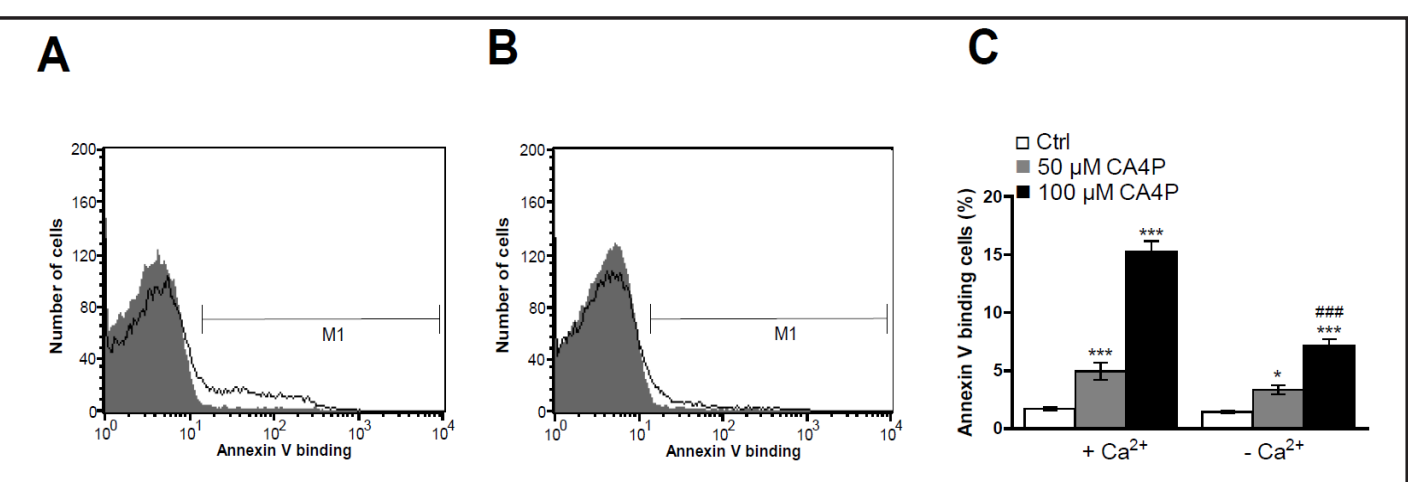

Fig. 4. $\mathrm{Ca}^{2+}$ sensitivity of CA4P -induced phosphatidylserine exposure. A,B. Original histogram of annexinV-binding of erythrocytes following exposure for 48 hours to Ringer solution without (grey areas) and with (black lines) CA4P $(100 \mu \mathrm{M})$ in the presence (A) and absence (B) of extracellular $\mathrm{Ca}^{2+}$. C. Arithmetic means \pm SEM ( $n=10)$ of annexin-V-binding of erythrocytes after a 48 hours treatment with Ringer solution without (white bars) or with (grey, black bars) 50 and $100 \mu \mathrm{M}$ CA4P, respectively, in the presence (left bars, $+\mathrm{Ca}^{2+}$ ) and absence (right bars, $\left.-\mathrm{Ca}^{2+}\right)$ of $\mathrm{Ca}^{2+} . *(\mathrm{p}<0.05),{ }^{* * *}(\mathrm{p}<0.001)$ indicates significant difference from the absence of CA4P, \#\#\#(p<0.001) indicates significant difference from the presence of $\mathrm{Ca}^{2+}(\mathrm{ANOVA})$.

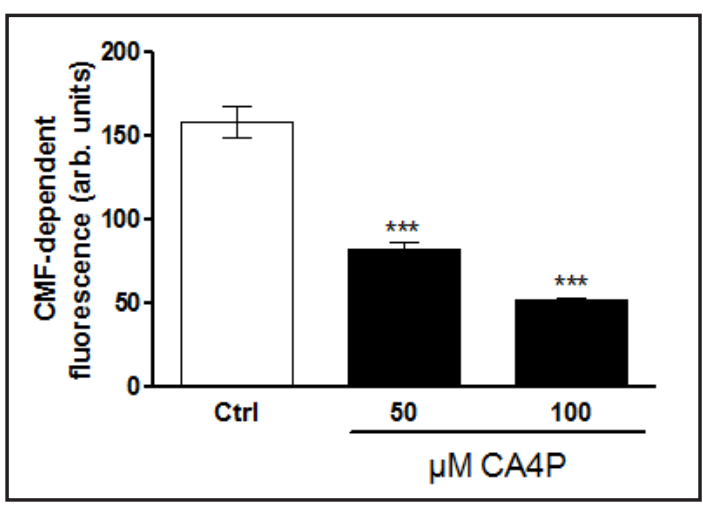

Fig. 5. Effect of CA4P on erythrocyte glutathione $(\mathrm{GSH})$ abundance. Arithmetic means \pm SEM $(\mathrm{n}=10)$ of the CMF fluorescence (arbitrary units) in erythrocytes exposed for 48 hours to Ringer solution without (white bar) or with (black bars) 50 and $100 \mu \mathrm{M}$ CA4P. ${ }^{* * *}(\mathrm{p}<0.001)$ indicates significant difference from the absence of CA4P (ANOVA).

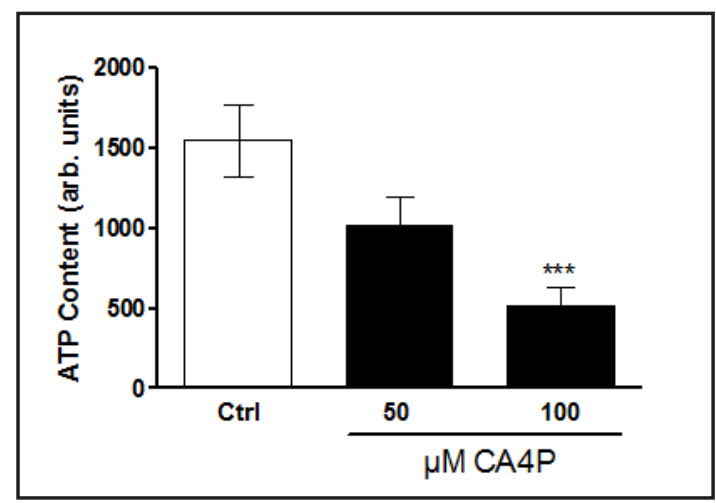

Fig. 6. Effect of CA4P on erythrocyte ATP concentration. Arithmetic means \pm SEM $(n=5)$ of the cytosolic ATP concentrations (arb. units) in erythrocytes exposed for 48 hours to Ringer solution without (white bar) or with (black bars) 50 and $100 \mu \mathrm{M}$ CA4P. *** $(p<0.001)$ indicate significant difference from the absence of CA4P (ANOVA).

Eryptosis could further be stimulated by ceramide. Ceramide abundance at the erythrocyte surface was thus quantified with flow cytometry utilizing specific antibodies. As a result, the ceramide abundance was similar following exposure to $50 \mu \mathrm{M}(9.9 \pm 0.1$ a.u., $\mathrm{n}=$ $10)$ or $100 \mu \mathrm{M}(10.6 \pm 0.2$ a.u., $\mathrm{n}=10) \mathrm{CA} 4 \mathrm{P}$ concentration and following exposure to Ringer solution $(10.4 \pm 0.1$ a.u., $\mathrm{n}=10)$. Thus, a 48 hours exposure to CA4P $(50$ and $100 \mu \mathrm{M})$ did not significantly modify ceramide abundance.

In order to explore whether CA4P triggers energy depletion, ATP levels were determined utilizing a luciferin-luciferase assay. As illustrated in Fig. 6, a 48 hours exposure to $100 \mu \mathrm{M}$ CA4P significantly decreased the cytosolic ATP levels (by 66\%).

\section{Discussion}

The present observations reveal a novel effect of CA4P, i.e. the triggering of suicidal erythrocyte death or eryptosis. Exposure of human erythrocytes to CA4P results in cell shrinkage 
and cell membrane scrambling with phosphatidylserine translocation to the erythrocyte surface. The CA4P concentrations required for the stimulation of eryptosis are in the range of concentrations encountered in the plasma of patients [41]. The higher concentrations employed here (50 and $100 \mu \mathrm{M})$ would be approached, however, only following intake of toxic drug doses.

The effect of CA4P on cell membrane scrambling was in large part dependent on $\mathrm{Ca}^{2+}$ entry from the extracellular space, as removal of extracellular $\mathrm{Ca}^{2+}$ significantly blunted CA4P induced phosphatidylserine translocation. Nevertheless, even in the absence of extracellular $\mathrm{Ca}^{2+}, \mathrm{CA} 4 \mathrm{P}$ was able to significantly trigger cell membrane scrambling. The effect of CA4P on cell shrinkage was again presumably in part due to $\mathrm{Ca}^{2+}$ entry. An increase of $\left[\mathrm{Ca}^{2+}\right]_{i}$ is expected to activate $\mathrm{Ca}^{2+}$ sensitive $\mathrm{K}^{+}$channels with subsequent $\mathrm{K}^{+}$exit, cell membrane hyperpolarization, $\mathrm{Cl}^{-}$exit and thus cellular loss of $\mathrm{KCl}$ with water [65].

Eryptosis is a physiological mechanism accomplishing clearance of defective erythrocytes from circulating blood prior to hemolysis [65]. Hemolysis of defective erythrocytes leads to release of hemoglobin, which passes the renal glomerular filter, precipitates in the acidic lumen of renal tubules, occludes nephrons and may thus trigger renal failure [101]. Eryptosis is further pivotal for the elimination of erythrocytes infected with the malaria pathogen Plasmodium [65].

As phosphatidylserine exposing erythrocytes are rapidly cleared from circulating blood, stimulation of eryptosis may lead to anemia as soon as the loss of erythrocytes outcasts the formation of new erythrocytes by erythropoiesis [65]. Phosphatidylserine exposing erythrocytes further adhere to the vascular wall [102], stimulate blood clotting and trigger thrombosis [103-105], thus impairing microcirculation [67, 103, 106-109].

The sensitivity of erythrocytes to CA4P treatment is presumably enhanced in several eryptosis-inducing clinical conditions, such as dehydration [110], hyperphosphatemia [111], chronic kidney disease (CKD) [112-115], hemolytic-uremic syndrome [116], diabetes [117], hepatic failure [118], malignancy [65], sepsis [119], sickle-cell disease [65], beta-thalassemia [65], Hb-C and G6PD-deficiency [65], as well as Wilsons disease [120]. The possibility of enhanced CA4P toxicity in those clinical conditions should be taken into consideration.

In conclusion, CA4P triggers eryptosis with cell shrinkage and cell membrane scrambling, an effect apparently in large part due to stimulation of $\mathrm{Ca}^{2+}$ entry.

\section{Acknowledgements}

The authors acknowledge the meticulous preparation of the manuscript by Tanja Loch. The study was supported by the Deutsche Forschungsgemeinschaft and the Open Access Publishing Fund of Tuebingen University.

\section{Disclosure Statement}

The authors of this manuscript state that they have no conflicts of interest to declare.

\section{References}

1 Abma E, Daminet S, Smets P, Ni Y, de Rooster H: Combretastatin A4-phosphate and its potential in veterinary oncology: a review. Vet Comp Oncol 2015;10.1111/vco.12150

2 Daswani VP, Ayesa U, Venegas B, Chong PL: Concentration-Induced J-Aggregate Formation Causes a Biphasic Change in the Release of trans-Combretastatin A4 Disodium Phosphate from Archaeosomes and the Subsequent Cytotoxicity on Mammary Cancer Cells. Mol Pharm 2015;12:3724-3734.

3 Feng D, Menger MD, Laschke MW: Vascular disrupting effects of combretastatin A4 phosphate on murine endometriotic lesions. Fertil Steril 2013;100:1459-1467.

4 Greene LM, O'Boyle NM, Nolan DP, Meegan MJ, Zisterer DM: The vascular targeting agent Combretastatin-A4 directly induces autophagy in adenocarcinoma-derived colon cancer cells. Biochem Pharmacol 2012;84:612-624. 


\section{Cellular Physiology Cell Physiol Biochem 2016;38:969-981 \begin{tabular}{l|l|l} 
DOI: 10.1159/000443049 2016 & $\begin{array}{l}\text { () 2016 The Author(s). Published by S. Karger AG, Basel } \\
\text { www.karger.com/cpb }\end{array}$
\end{tabular}}

Signoretto et al.: CA4P-Induced Eryptosis

5 Li J, Chen F, Feng Y, Cona MM, Yu J, Verbruggen A, Zhang J, Oyen R, Ni Y: Diverse responses to vascular disrupting agent combretastatin a4 phosphate: a comparative study in rats with hepatic and subcutaneous tumor allografts using MRI biomarkers, microangiography, and histopathology. Transl Oncol 2013;6:42-50.

6 Liu P, Qin Y, Wu L, Yang S, Li N, Wang H, Xu H, Sun K, Zhang S, Han X, Sun Y, Shi Y: A phase I clinical trial assessing the safety and tolerability of combretastatin A4 phosphate injections. Anticancer Drugs 2014;25:462-471.

7 Nagaiah G, Remick SC: Combretastatin A4 phosphate: a novel vascular disrupting agent. Future Oncol 2010;6:1219-1228.

8 Su J, Laursen BE, Eskildsen-Helmond Y, Horsman MR, Simonsen U: The vascular-disrupting agent, combretastatin-A4-phosphate, enhances neurogenic vasoconstriction in rat small arteries. Eur J Pharmacol 2012;695:104-111.

9 Welford AF, Biziato D, Coffelt SB, Nucera S, Fisher M, Pucci F, Di Serio C, Naldini L, De Palma M, Tozer GM, Lewis CE: TIE2-expressing macrophages limit the therapeutic efficacy of the vascular-disrupting agent combretastatin A4 phosphate in mice. J Clin Invest 2011;121:1969-1973.

10 Zhu J, Xu X, Hu M, Qiu L: Co-Encapsulation of Combretastatin-A4 Phosphate and Doxorubicin in Polymersomes for Synergistic Therapy of Nasopharyngeal Epidermal Carcinoma. J Biomed Nanotechnol 2015;11:997-1006.

11 Siemann DW, Chaplin DJ, Walicke PA: A review and update of the current status of the vasculature-disabling agent combretastatin-A4 phosphate (CA4P). Expert Opin Investig Drugs 2009;18:189-197.

12 Wang H, Sun X, Chen F, De Keyzer F, Yu J, Landuyt W, Vandecaveye V, Peeters R, Bosmans H, Hermans R, Marchal G, Ni Y: Treatment of rodent liver tumor with combretastatin a4 phosphate: noninvasive therapeutic evaluation using multiparametric magnetic resonance imaging in correlation with microangiography and histology. Invest Radiol 2009;44:44-53.

13 Chen G, Horsman MR, Pedersen M, Pang Q, Stodkilde-Jorgensen H: The effect of combretastatin A4 disodium phosphate and 5,6-dimethylxanthenone-4-acetic acid on water diffusion and blood perfusion in tumours. Acta Oncol 2008;47:1071-1076.

14 Gaya A, Daley F, Taylor NJ, Tozer G, Qureshi U, Padhani A, Pedley RB, Begent R, Wellsted D, Stirling JJ, Rustin G: Relationship between human tumour angiogenic profile and combretastatin-induced vascular shutdown: an exploratory study. Br J Cancer 2008;99:321-326.

15 McPhail LD, Griffiths JR, Robinson SP: Assessment of tumor response to the vascular disrupting agents 5,6-dimethylxanthenone-4-acetic acid or combretastatin-A4-phosphate by intrinsic susceptibility magnetic resonance imaging. Int J Radiat Oncol Biol Phys 2007;69:1238-1245.

16 Zhao D, Richer E, Antich PP, Mason RP: Antivascular effects of combretastatin A4 phosphate in breast cancer xenograft assessed using dynamic bioluminescence imaging and confirmed by MRI. FASEB J 2008;22:2445-2451.

17 Ley CD, Horsman MR, Kristjansen PE: Early effects of combretastatin-A4 disodium phosphate on tumor perfusion and interstitial fluid pressure. Neoplasia 2007;9:108-112.

18 Ng QS, Goh V, Carnell D, Meer K, Padhani AR, Saunders MI, Hoskin PJ: Tumor antivascular effects of radiotherapy combined with combretastatin a4 phosphate in human non-small-cell lung cancer. Int J Radiat Oncol Biol Phys 2007;67:1375-1380.

19 Cooney MM, Ortiz J, Bukowski RM, Remick SC: Novel vascular targeting/disrupting agents: combretastatin A4 phosphate and related compounds. Curr Oncol Rep 2005;7:90-95.

20 Vincent L, Kermani P, Young LM, Cheng J, Zhang F, Shido K, Lam G, Bompais-Vincent H, Zhu Z, Hicklin DJ, Bohlen P, Chaplin DJ, May C, Rafii S: Combretastatin A4 phosphate induces rapid regression of tumor neovessels and growth through interference with vascular endothelial-cadherin signaling. J Clin Invest 2005; 115:2992-3006.

21 Zhao D, Jiang L, Hahn EW, Mason RP: Tumor physiologic response to combretastatin A4 phosphate assessed by MRI. Int J Radiat Oncol Biol Phys 2005;62:872-880.

22 West CM, Price P: Combretastatin A4 phosphate. Anticancer Drugs 2004;15:179-187.

23 Anderson HL, Yap JT, Miller MP, Robbins A, Jones T, Price PM: Assessment of pharmacodynamic vascular response in a phase I trial of combretastatin A4 phosphate. J Clin Oncol 2003;21:2823-2830.

24 Chaplin DJ: Drug based approaches for targeting tumor vasculature: development of combretastatin A4 phosphate. Pathophysiol Haemost Thromb 2003;33:S9-10. 


\section{Cellular Physiology Cell Physiol Biochem 2016;38:969-981 \begin{tabular}{l|l|l}
\hline and Biochemistry 10.1159/000443049 & $\begin{array}{l}\text { ( ) 2016 The Author(s). Published by S. Karger AG, Basel } \\
\text { www.karger.com/cpb }\end{array}$
\end{tabular}}

Signoretto et al.: CA4P-Induced Eryptosis

25 Galbraith SM, Maxwell RJ, Lodge MA, Tozer GM, Wilson J, Taylor NJ, Stirling JJ, Sena L, Padhani AR, Rustin GJ: Combretastatin A4 phosphate has tumor antivascular activity in rat and man as demonstrated by dynamic magnetic resonance imaging. J Clin Oncol 2003;21:2831-2842.

26 Stevenson JP, Rosen M, Sun W, Gallagher M, Haller DG, Vaughn D, Giantonio B, Zimmer R, Petros WP, Stratford M, Chaplin D, Young SL, Schnall M, O'Dwyer PJ: Phase I trial of the antivascular agent combretastatin A4 phosphate on a 5-day schedule to patients with cancer: magnetic resonance imaging evidence for altered tumor blood flow. J Clin Oncol 2003;21:4428-4438.

27 Chaplin DJ, Hill SA: The development of combretastatin A4 phosphate as a vascular targeting agent. Int J Radiat Oncol Biol Phys 2002;54:1491-1496.

28 Dowlati A, Robertson K, Cooney M, Petros WP, Stratford M, Jesberger J, Rafie N, Overmoyer B, Makkar V, Stambler B, Taylor A, Waas J, Lewin JS, McCrae KR, Remick SC: A phase I pharmacokinetic and translational study of the novel vascular targeting agent combretastatin a-4 phosphate on a single-dose intravenous schedule in patients with advanced cancer. Cancer Res 2002;62:3408-3416.

29 Rojiani AM, Li L, Rise L, Siemann DW: Activity of the vascular targeting agent combretastatin A-4 disodium phosphate in a xenograft model of AIDS-associated Kaposi's sarcoma. Acta Oncol 2002;41:98-105.

30 Beauregard DA, Hill SA, Chaplin DJ, Brindle KM: The susceptibility of tumors to the antivascular drug combretastatin A4 phosphate correlates with vascular permeability. Cancer Res 2001;61:6811-6815.

31 Beauregard DA, Pedley RB, Hill SA, Brindle KM: Differential sensitivity of two adenocarcinoma xenografts to the anti-vascular drugs combretastatin A4 phosphate and 5,6-dimethylxanthenone-4-acetic acid, assessed using MRI and MRS. NMR Biomed 2002;15:99-105.

32 Griggs J, Metcalfe JC, Hesketh R: Targeting tumour vasculature: the development of combretastatin A4. Lancet Oncol 2001;2:82-87.

33 Griggs J, Hesketh R, Smith GA, Brindle KM, Metcalfe JC, Thomas GA, Williams ED: Combretastatin-A4 disrupts neovascular development in non-neoplastic tissue. Br J Cancer 2001;84:832-835.

34 Beauregard DA, Thelwall PE, Chaplin DJ, Hill SA, Adams GE, Brindle KM: Magnetic resonance imaging and spectroscopy of combretastatin A4 prodrug-induced disruption of tumour perfusion and energetic status. Br J Cancer 1998;77:1761-1767.

35 Chaplin DJ, Pettit GR, Hill SA: Anti-vascular approaches to solid tumour therapy: evaluation of combretastatin A4 phosphate. Anticancer Res 1999;19:189-195.

36 Wakaskar RR, Bathena SP, Tallapaka SB, Ambardekar VV, Gautam N, Thakare R, Simet SM, Curran SM, Singh RK, Dong Y, Vetro JA: Peripherally cross-linking the shell of core-shell polymer micelles decreases premature release of physically loaded combretastatin A4 in whole blood and increases its mean residence time and subsequent potency against primary murine breast tumors after IV administration. Pharm Res 2015;32:1028-1044.

37 Yao N, Ren K, Jiang C, Gao M, Huang D, Lu X, Lou B, Peng F, Yang A, Wang X, Ni Y, Zhang J: Combretastatin A4 phosphate treatment induces vasculogenic mimicry formation of W256 breast carcinoma tumor in vitro and in vivo. Tumour Biol 2015;36:8499-8510.

38 Li J, Cona MM, Chen F, Feng Y, Zhou L, Zhang G, Nuyts J, de Witte P, Zhang J, Yu J, Oyen R, Verbruggen A, Ni Y: Sequential systemic administrations of combretastatin A4 Phosphate and radioiodinated hypericin exert synergistic targeted theranostic effects with prolonged survival on SCID mice carrying bifocal tumor xenografts. Theranostics 2013;3:127-137.

39 Fu XH, Li J, Zou Y, Hong YR, Fu ZX, Huang JJ, Zhang SZ, Zheng S: Endostar enhances the antineoplastic effects of combretastatin A4 phosphate in an osteosarcoma xenograft. Cancer Lett 2011;312:109-116.

40 Nathan P, Zweifel M, Padhani AR, Koh DM, Ng M, Collins DJ, Harris A, Carden C, Smythe J, Fisher N, Taylor NJ, Stirling JJ, Lu SP, Leach MO, Rustin GJ, Judson I: Phase I trial of combretastatin A4 phosphate (CA4P) in combination with bevacizumab in patients with advanced cancer. Clin Cancer Res 2012;18:3428-3439.

41 He X, Li S, Huang H, Li Z, Chen L, Ye S, Huang J, Zhan J, Lin T: A pharmacokinetic and safety study of single dose intravenous combretastatin A4 phosphate in Chinese patients with refractory solid tumours. Br J Clin Pharmacol 2011;71:860-870.

42 Ng QS, Mandeville H, Goh V, Alonzi R, Milner J, Carnell D, Meer K, Padhani AR, Saunders MI, Hoskin PJ: Phase Ib trial of radiotherapy in combination with combretastatin-A4-phosphate in patients with nonsmall-cell lung cancer, prostate adenocarcinoma, and squamous cell carcinoma of the head and neck. Ann Oncol 2012;23:231-237. 


\section{Cellular Physiology Cell Physiol Biochem 2016;38:969-981 \begin{tabular}{l|l|l} 
and Biochemistry 10.1159/000443049 & $\begin{array}{l}\text { D } 2016 \text { The Author(s). Published by S. Karger AG, Basel } \\
\text { www.karger.com/cpb }\end{array}$
\end{tabular}}

Signoretto et al.: CA4P-Induced Eryptosis

43 Shao H, Ni Y, Dai X, Zhang J, Chen F, Fan G, Sun Z, Li Y, Zhou H, Xu K: Diffusion-weighted MR imaging allows monitoring the effect of combretastatin A4 phosphate on rabbit implanted VX2 tumor model: 12-day dynamic results. Eur J Radiol 2012;81:578-583.

44 Meyer T, Gaya AM, Dancey G, Stratford MR, Othman S, Sharma SK, Wellsted D, Taylor NJ, Stirling JJ, Poupard L, Folkes LK, Chan PS, Pedley RB, Chester KA, Owen K, Violet JA, Malaroda A, Green AJ, Buscombe J, Padhani AR, Rustin GJ, Begent RH: A phase I trial of radioimmunotherapy with 131I-A5B7 anti-CEA antibody in combination with combretastatin-A4-phosphate in advanced gastrointestinal carcinomas. Clin Cancer Res 2009;15:4484-4492.

45 Rustin GJ, Shreeves G, Nathan PD, Gaya A, Ganesan TS, Wang D, Boxall J, Poupard L, Chaplin DJ, Stratford MR, Balkissoon J, Zweifel M: A Phase Ib trial of CA4P (combretastatin A-4 phosphate), carboplatin, and paclitaxel in patients with advanced cancer. Br J Cancer 2010;102:1355-1360.

46 Zweifel M, Jayson GC, Reed NS, Osborne R, Hassan B, Ledermann J, Shreeves G, Poupard L, Lu SP, Balkissoon J, Chaplin DJ, Rustin GJ: Phase II trial of combretastatin A4 phosphate, carboplatin, and paclitaxel in patients with platinum-resistant ovarian cancer. Ann Oncol 2011;22:2036-2041.

47 Koh DM, Blackledge M, Collins DJ, Padhani AR, Wallace T, Wilton B, Taylor NJ, Stirling JJ, Sinha R, Walicke P, Leach MO, Judson I, Nathan P: Reproducibility and changes in the apparent diffusion coefficients of solid tumours treated with combretastatin A4 phosphate and bevacizumab in a two-centre phase I clinical trial. Eur Radiol 2009;19:2728-2738.

48 Mitrus I, Sochanik A, Cichon T, Szala S: Combination of combretastatin A4 phosphate and doxorubicincontaining liposomes affects growth of B16-F10 tumors. Acta Biochim Pol 2009;56:161-165.

49 Salmon BA, Siemann DW: Characterizing the tumor response to treatment with combretastatin A4 phosphate. Int J Radiat Oncol Biol Phys 2007;68:211-217.

50 Lankester KJ, Maxwell RJ, Pedley RB, Dearling JL, Qureshi UA, El-Emir E, Hill SA, Tozer GM: Combretastatin A-4-phosphate effectively increases tumor retention of the therapeutic antibody, 131I-A5B7, even at doses that are sub-optimal for vascular shut-down. Int J Oncol 2007;30:453-460.

51 Badn W, Kalliomaki S, Widegren B, Sjogren HO: Low-dose combretastatin A4 phosphate enhances the immune response of tumor hosts to experimental colon carcinoma. Clin Cancer Res 2006;12:4714-4719.

52 Thomas CD, Walczak C, Kaffy J, Pontikis R, Jouanneau J, Volk A: Early effects of combretastatin A4 phosphate assessed by anatomic and carbogen-based functional magnetic resonance imaging on rat bladder tumors implanted in nude mice. Neoplasia 2006;8:587-595.

53 Young SL, Chaplin DJ: Combretastatin A4 phosphate: background and current clinical status. Expert Opin Investig Drugs 2004;13:1171-1182.

54 Cooney MM, Radivoyevitch T, Dowlati A, Overmoyer B, Levitan N, Robertson K, Levine SL, DeCaro K, Buchter C, Taylor A, Stambler BS, Remick SC: Cardiovascular safety profile of combretastatin a4 phosphate in a single-dose phase I study in patients with advanced cancer. Clin Cancer Res 2004;10:96-100.

55 Kirwan IG, Loadman PM, Swaine DJ, Anthoney DA, Pettit GR, Lippert JW, 3rd, Shnyder SD, Cooper PA, Bibby MC: Comparative preclinical pharmacokinetic and metabolic studies of the combretastatin prodrugs combretastatin A4 phosphate and A1 phosphate. Clin Cancer Res 2004;10:1446-1453.

56 Dziba JM, Marcinek R, Venkataraman G, Robinson JA, Ain KB: Combretastatin A4 phosphate has primary antineoplastic activity against human anaplastic thyroid carcinoma cell lines and xenograft tumors. Thyroid 2002;12:1063-1070.

57 Rustin GJ, Galbraith SM, Anderson H, Stratford M, Folkes LK, Sena L, Gumbrell L, Price PM: Phase I clinical trial of weekly combretastatin A4 phosphate: clinical and pharmacokinetic results. J Clin Oncol 2003;21:2815-2822.

58 Hill SA, Chaplin DJ, Lewis G, Tozer GM: Schedule dependence of combretastatin A4 phosphate in transplanted and spontaneous tumour models. Int J Cancer 2002;102:70-74.

59 Galbraith SM, Chaplin DJ, Lee F, Stratford MR, Locke RJ, Vojnovic B, Tozer GM: Effects of combretastatin A4 phosphate on endothelial cell morphology in vitro and relationship to tumour vascular targeting activity in vivo. Anticancer Res 2001;21:93-102.

60 Dorr RT, Dvorakova K, Snead K, Alberts DS, Salmon SE, Pettit GR: Antitumor activity of combretastatin-A4 phosphate, a natural product tubulin inhibitor. Invest New Drugs 1996;14:131-137.

61 Grosios K, Loadman PM, Swaine DJ, Pettit GR, Bibby MC: Combination chemotherapy with combretastatin A-4 phosphate and 5-fluorouracil in an experimental murine colon adenocarcinoma. Anticancer Res 2000;20:229-233. 


\section{Cellular Physiology Cell Physiol Biochem 2016;38:969-981 \begin{tabular}{l|l} 
and Biochemistry POI: 10.1159/000443049 2016 & $\begin{array}{l}\text { (c) 2016 The Author(s). Published by S. Karger AG, Basel } \\
\text { www.karger.com/cpb }\end{array}$ \\
\hline
\end{tabular} \\ Signoretto et al.: CA4P-Induced Eryptosis}

62 Yeung SC, She M, Yang H, Pan J, Sun L, Chaplin D: Combination chemotherapy including combretastatin A4 phosphate and paclitaxel is effective against anaplastic thyroid cancer in a nude mouse xenograft model. J Clin Endocrinol Metab 2007;92:2902-2909.

63 Lin HL, Chiou SH, Wu CW, Lin WB, Chen LH, Yang YP, Tsai ML, Uen YH, Liou JP, Chi CW: Combretastatin A4-induced differential cytotoxicity and reduced metastatic ability by inhibition of AKT function in human gastric cancer cells. J Pharmacol Exp Ther 2007;323:365-373.

64 Ding X, Zhang Z, Li S, Wang A: Combretastatin A4 phosphate induces programmed cell death in vascular endothelial cells. Oncol Res 2011;19:303-309.

65 Lang E, Lang F: Mechanisms and pathophysiological significance of eryptosis, the suicidal erythrocyte death. Semin Cell Dev Biol 2015;39:35-42.

66 Lang PA, Kaiser S, Myssina S, Wieder T, Lang F, Huber SM: Role of Ca2+-activated K+ channels in human erythrocyte apoptosis. Am J Physiol Cell Physiol 2003;285:C1553-C1560.

67 Abed M, Towhid ST, Mia S, Pakladok T, Alesutan I, Borst O, Gawaz M, Gulbins E, Lang F: Sphingomyelinaseinduced adhesion of eryptotic erythrocytes to endothelial cells. Am J Physiol Cell Physiol 2012;303:C991999.

68 Lau IP, Chen H, Wang J, Ong HC, Leung KC, Ho HP, Kong SK: In vitro effect of CTAB- and PEG-coated gold nanorods on the induction of eryptosis/erythroptosis in human erythrocytes. Nanotoxicology 2012;6:847856.

69 Maellaro E, Leoncini S, Moretti D, Del Bello B, Tanganelli I, De Felice C, Ciccoli L: Erythrocyte caspase-3 activation and oxidative imbalance in erythrocytes and in plasma of type 2 diabetic patients. Acta Diabetol 2013;50:489-495.

70 Alzoubi K, Calabròa S, Bissinger R, Abed M, Faggio C, Lang F: Stimulation of Suicidal Erythrocyte Death by Artesunate. Cell Physiol Biochem 2014;34:2232-2244.

71 Alzoubi K, Egler J, Abed M, Lang F: Enhanced Eryptosis Following Auranofin Exposure. Cell Physiol Biochem 2015;37:1018-1028.

72 Arnold M, Bissinger R, Lang F: Mitoxantrone-induced suicidal erythrocyte death. Cell Physiol Biochem 2014;34:1756-1767.

73 Arnold M, Lang E, Modicano P, Bissinger R, Faggio C, Abed M, Lang F: Effect of nitazoxanide on erythrocytes. Basic Clin Pharmacol Toxicol 2014;114:421-426.

74 Bissinger R, Barking S, Alzoubi K, Liu G, Liu G, Lang F: Stimulation of Suicidal Erythrocyte Death by the Antimalarial Drug Mefloquine. Cell Physiol Biochem 2015;36:1395-1405.

75 Bissinger R, Bouguerra G, Stockinger K, Abbes S, Lang F: Triggering of Suicidal Erythrocyte Death by Topotecan. Cell Physiol Biochem 2015;37:1607-1618.

76 Bissinger R, Fischer S, Jilani K, Lang F: Stimulation of Erythrocyte Death by Phloretin. Cell Physiol Biochem 2014;34:2256-2265.

77 Bissinger R, Lupescu A, Zelenak C, Jilani K, Lang F: Stimulation of eryptosis by cryptotanshinone. Cell Physiol Biochem 2014;34:432-442.

78 Bouguerra G, Aljanadi O, Bissinger R, Abbes S, Lang F: Embelin-Induced Phosphatidylserine Translocation in the Erythrocyte Cell Membrane. Cell Physiol Biochem 2015;37:1629-1640.

79 Bouguerra G, Bissinger R, Abbes S, Lang F: Stimulation of Eryptosis by Narasin. Cell Physiol Biochem 2015;37:1807-1816.

80 Bouguerra G, Bissinger R, Abbes S, Lang F: Zopolrestat Induced Suicidal Death of Human Erythrocytes. Cell Physiol Biochem 2015;37:1537-1546.

81 Briglia M, Fazio A, Faggio C, Laufer S, Alzoubi K, Lang F: Triggering of Suicidal Erythrocyte Death by Ruxolitinib. Cell Physiol Biochem 2015;37:768-778.

82 Briglia M, Fazio A, Signoretto E, Faggio C, Lang F: Edelfosine Induced Suicidal Death of Human Erythrocytes. Cell Physiol Biochem 2015;37:2221-2230.

83 Calabro S, Alzoubi K, Faggio C, Laufer S, Lang F: Triggering of Suicidal Erythrocyte Death Following Boswellic Acid Exposure. Cell Physiol Biochem 2015;37:131-142.

84 Egler J, Lang F: Licochalcone A Induced Suicidal Death of Human Erythrocytes. Cell Physiol Biochem 2015;37:2060-2070.

85 Faggio C, Alzoubi K, Calabro S, Lang F: Stimulation of suicidal erythrocyte death by PRIMA-1. Cell Physiol Biochem 2015;35:529-540. 


\section{Cellular Physiology Cell Physiol Biochem 2016;38:969-981

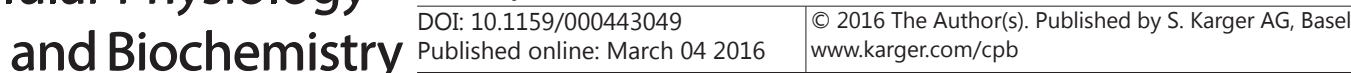

Signoretto et al.: CA4P-Induced Eryptosis

86 Fazio A, Briglia M, Faggio C, Alzoubi K, Lang F: Stimulation of Suicidal Erythrocyte Death by Garcinol. Cell Physiol Biochem 2015;37:805-815.

87 Jacobi J, Lang E, Bissinger R, Frauenfeld L, Modicano P, Faggio C, Abed M, Lang F: Stimulation of erythrocyte cell membrane scrambling by mitotane. Cell Physiol Biochem 2014;33:1516-1526.

88 Lang E, Jilani K, Bissinger R, Rexhepaj R, Zelenak C, Lupescu A, Lang F, Qadri SM: Vitamin D-Rich Diet in Mice Modulates Erythrocyte Survival. Kidney Blood Press Res 2015;40:403-412.

89 Lang E, Zelenak C, Eberhard M, Bissinger R, Rotte A, Ghashghaeinia M, Lupescu A, Lang F, Qadri SM: Impact of Cyclin-Dependent Kinase CDK4 Inhibition on Eryptosis. Cell Physiol Biochem 2015;37:1178-1186.

90 Lupescu A, Bissinger R, Goebel T, Salker MS, Alzoubi K, Liu G, Chirigiu L, Mack AF, Qadri SM, Lang F: Enhanced suicidal erythrocyte death contributing to anemia in the elderly. Cell Physiol Biochem 2015;36:773-783.

91 Lupescu A, Bissinger R, Herrmann T, Oswald G, Jilani K, Lang F: Induction of suicidal erythrocyte death by novobiocin. Cell Physiol Biochem 2014;33:670-680.

92 Lupescu A, Bissinger R, Warsi J, Jilani K, Lang F: Stimulation of erythrocyte cell membrane scrambling by gedunin. Cell Physiol Biochem 2014;33:1838-1848.

93 Malik A, Bissinger R, Calabro S, Faggio C, Jilani K, Lang F: Aristolochic Acid Induced Suicidal Erythrocyte Death. Kidney Blood Press Res 2014;39:408-419.

94 Officioso A, Alzoubi K, Manna C, Lang F: Clofazimine Induced Suicidal Death of Human Erythrocytes. Cell Physiol Biochem 2015;37:331-341.

95 Oswald G, Alzoubi K, Abed M, Lang F: Stimulation of suicidal erythrocyte death by ribavirin. Basic Clin Pharmacol Toxicol 2014;114:311-317.

96 Peter T, Bissinger R, Enkel S, Alzoubi K, Oswald G, Lang F: Programmed erythrocyte death following in vitro Treosulfan treatment. Cell Physiol Biochem 2015;35:1372-1380.

97 Stockinger K, Bissinger R, Bouguerra G, Abbes S, Lang F: Enhanced Eryptosis Following Exposure to Carnosic Acid. Cell Physiol Biochem 2015;37:1779-1791.

98 Tesoriere L, Attanzio A, Allegra M, Cilla A, Gentile C, Livrea MA: Oxysterol mixture in hypercholesterolemiarelevant proportion causes oxidative stress-dependent eryptosis. Cell Physiol Biochem 2014;34:10751089.

99 Waibel S, Bissinger R, Bouguerra G, Abbes S, Lang F: Saquinavir Induced Suicidal Death of Human Erythrocytes. Cell Physiol Biochem 2015;37:1973-1982.

100 Zierle J, Bissinger R, Egler J, Lang F: Lapatinib Induced Suicidal Death of Human Erythrocytes. Cell Physiol Biochem 2015;37:2275-2287.

101 Harrison HE, Bunting H, Ordway NK, Albrink WS: The Pathogenesis of the Renal Injury Produced in the Dog by Hemoglobin or Methemoglobin. J Exp Med 1947;86:339-356.

102 Borst O, Abed M, Alesutan I, Towhid ST, Qadri SM, Foller M, Gawaz M, Lang F: Dynamic adhesion of eryptotic erythrocytes to endothelial cells via CXCL16/SR-PSOX. Am J Physiol Cell Physiol 2012;302:C644-C651.

103 Andrews DA, Low PS: Role of red blood cells in thrombosis. Curr Opin Hematol 1999;6:76-82.

104 Chung SM, Bae ON, Lim KM, Noh JY, Lee MY, Jung YS, Chung JH: Lysophosphatidic acid induces thrombogenic activity through phosphatidylserine exposure and procoagulant microvesicle generation in human erythrocytes. Arterioscler Thromb Vasc Biol 2007;27:414-421.

105 Zwaal RF, Comfurius P, Bevers EM: Surface exposure of phosphatidylserine in pathological cells. Cell Mol Life Sci 2005;62:971-988.

106 Closse C, Dachary-Prigent J, Boisseau MR: Phosphatidylserine-related adhesion of human erythrocytes to vascular endothelium. Br J Haematol 1999;107:300-302.

107 Gallagher PG, Chang SH, Rettig MP, Neely JE, Hillery CA, Smith BD, Low PS: Altered erythrocyte endothelial adherence and membrane phospholipid asymmetry in hereditary hydrocytosis. Blood 2003;101:46254627.

108 Pandolfi A, Di Pietro N, Sirolli V, Giardinelli A, Di Silvestre S, Amoroso L, Di Tomo P, Capani F, Consoli A, Bonomini M: Mechanisms of uremic erythrocyte-induced adhesion of human monocytes to cultured endothelial cells. J Cell Physiol 2007;213:699-709.

109 Wood BL, Gibson DF, Tait JF: Increased erythrocyte phosphatidylserine exposure in sickle cell disease: flow-cytometric measurement and clinical associations. Blood 1996;88:1873-1880. 


\section{Cellular Physiology Cell Physiol Biochem 2016;38:969-981 \begin{tabular}{ll|l} 
DOI: 10.1159/000443049 2016 & $\begin{array}{l}\text { O 2016 The Author(s). Published by S. Karger AG, Basel } \\
\text { www.karger.com/cpb }\end{array}$
\end{tabular}}

Signoretto et al.: CA4P-Induced Eryptosis

110 Abed M, Feger M, Alzoubi K, Pakladok T, Frauenfeld L, Geiger C, Towhid ST, Lang F: Sensitization of erythrocytes to suicidal erythrocyte death following water deprivation. Kidney Blood Press Res 2013;37:567-578.

111 Voelkl J, Alzoubi K, Mamar AK, Ahmed MS, Abed M, Lang F: Stimulation of suicidal erythrocyte death by increased extracellular phosphate concentrations. Kidney Blood Press Res 2013;38:42-51.

112 Abed M, Artunc F, Alzoubi K, Honisch S, Baumann D, Foller M, Lang F: Suicidal erythrocyte death in endstage renal disease. J Mol Med (Berl) 2014;92:871-879.

113 Ahmed MS, Langer H, Abed M, Voelkl J, Lang F: The uremic toxin acrolein promotes suicidal erythrocyte death. Kidney Blood Press Res 2013;37:158-167.

114 Polak-Jonkisz D, Purzyc L: Ca(2+) influx versus efflux during eryptosis in uremic erythrocytes. Blood Purif 2012;34:209-210; author reply 210.

115 Calderon-Salinas JV, Munoz-Reyes EG, Guerrero-Romero JF, Rodriguez-Moran M, Bracho-Riquelme RL, Carrera-Gracia MA, Quintanar-Escorza MA: Eryptosis and oxidative damage in type 2 diabetic mellitus patients with chronic kidney disease. Mol Cell Biochem 2011;357:171-179.

116 Lang PA, Beringer O, Nicolay JP, Amon O, Kempe DS, Hermle T, Attanasio P, Akel A, Schafer R, Friedrich B, Risler T, Baur M, Olbricht CJ, Zimmerhackl LB, Zipfel PF, Wieder T, Lang F: Suicidal death of erythrocytes in recurrent hemolytic uremic syndrome. J Mol Med (Berl) 2006;84:378-388.

117 Nicolay JP, Schneider J, Niemoeller OM, Artunc F, Portero-Otin M, Haik G Jr, Thornalley PJ, Schleicher E, Wieder T, Lang F: Stimulation of suicidal erythrocyte death by methylglyoxal. Cell Physiol Biochem 2006;18:223-232.

118 Lang E, Gatidis S, Freise NF, Bock H, Kubitz R, Lauermann C, Orth HM, Klindt C, Schuier M, Keitel V, Reich M, Liu G, Schmidt S, Xu HC, Qadri SM, Herebian D, Pandyra AA, Mayatepek E, Gulbins E, Lang F, Haussinger D, Lang KS, Foller M, Lang PA: Conjugated bilirubin triggers anemia by inducing erythrocyte death. Hepatology 2015;61:275-284.

119 Kempe DS, Akel A, Lang PA, Hermle T, Biswas R, Muresanu J, Friedrich B, Dreischer P, Wolz C, Schumacher U, Peschel A, Gotz F, Doring G, Wieder T, Gulbins E, Lang F: Suicidal erythrocyte death in sepsis. J Mol Med (Berl) 2007;85:273-281.

120 Lang PA, Schenck M, Nicolay JP, Becker JU, Kempe DS, Lupescu A, Koka S, Eisele K, Klarl BA, Rubben H, Schmid KW, Mann K, Hildenbrand S, Hefter H, Huber SM, Wieder T, Erhardt A, Haussinger D, Gulbins E, Lang F: Liver cell death and anemia in Wilson disease involve acid sphingomyelinase and ceramide. Nat Med 2007;13:164-170. 